\title{
Umberto Eco \\ w Łodzi, czyli Labirynt Znaków
}

Między 25 marca a 7 czerwca 2015 r. odbywał się w Łodzi festiwal „Labirynt Znaków 2015"1, którego gościem i bohaterem był Umberto Eco. Najważniejszym wydarzeniem festiwalu było przyznanie wybitnemu włoskiemu pisarzowi i semiologowi doktoratu honoris causa Uniwersytetu Łódzkiego².

Cykl ponad trzydziestu wydarzeń inspirowanych twórczością autora Imienia róży zainagurowany został niezwykle uroczyście - wystąpieniem Jego Ekscelencji Alessandra De Pedys, Ambasadora Włoch w Polsce. Zwieńczeniem festiwalu, zorganizowanego dla uczczenia 70. rocznicy istnienia Uniwersytetu Łódzkiego, było zaś uroczyste posiedzenie Senatu UŁ uświetnione obecnością gości z całego świata, m.in. żony Umberta Eco Renate Ramge, rektorów największych polskich uczelni, polityków, ambasadorów i konsulów honorowych. Rektor UŁ prof. Włodzimierz Nykiel odczytał listy od prezydenta Bronisława Komorowskiego oraz premier Ewy Kopacz, zaś laudację wygłosił profesor Artur Gałkowski, nazywając Eco: „wszechstronnym i niedoścignionym w kompetencjach autorytetem w Europie i na świecie”, „ambasadorem języka i kultury włoskiej” oraz „niekwestionowanym dobrem kultury".

Nie wszystkie wydarzenia składające się na Labirynt Znaków miały tak uroczysty i oficjalny charakter. Przeciwnie, między dwiema wspomnianymi uroczystościami zaplanowano wydarzenia w najróżniejszych konwencjach: trwały wystawy, konferencje, panele dyskusyjne, projekcje filmów, premiera polskiego wydania najnowszej powieści Eco pt. Temat na pierwsza strone $e^{3}$, warsztaty dla uczniów i seminaria dla nauczycieli, a nawet kryminalna noc literatury i gra miejska „W drodze do Ecolandii”.

1 Festiwal objęli honorowym patronatem: Ambasador Republiki Włoskiej w Polsce, Prezydent Miasta Łodzi, Rektor Uniwersytetu Łódzkiego, zaś współpatronatem: Istituto Italiano di Cultura di Varsavia, Oficyna Literacka Noir sur Blanc, Biblioteka Uniwersytecka UŁ, Rektor Akademii Sztuk Pięknych w Łodzi, Rektor Akademii Muzycznej w Łodzi.

2 Decyzja o przyznaniu włoskiemu pisarzowi i naukowcowi najwyższego wyróżnienia łódzkiego uniwersytetu zapadła na posiedzeniu Senatu UŁ 17 listopada 2014 roku. Recenzentami w postępowaniu o przyznanie tytułu zostali: prof. prof. Piotr Salwa, Tadeusz Sławek oraz Jarosław Płuciennik.

36 maja 2015 r., tłum. Krzysztof Żaboklicki, Noir sur Blanc, Warszawa 2015. 


\section{książka/literatura/biblioteka}

Festiwal już wieczorem 24 maja otwierała prezentacja dedykowanej Umbertowi Eco książki artystycznej pt. Potega intelektu ${ }^{4}$, zaprojektowanej przez Katarzynę Turkowską. Pozycja to niezwykła: zawiera nie tylko studia naukowe, ale również bibliografię podmiotową wszystkich dzieł Eco przetłumaczonych na język polski oraz bibliografię przedmiotową wydawnictw dotyczących Eco opublikowanych w Polsce od lat 60. do roku 2013. Okładka, zaprojektowana na kształt labiryntu w Knossos, symbolizuje otwartość dzieła. Szklana oprawa nawiązuje do ciężaru średniowiecznych ksiąg oprawianych w obijane skórą deski.

W drugiej części spotkania ogłoszono laureatów konkursu na włoskie tłumaczenie wierszy Wisławy Szymborskiej dla Umberta Eco. Gościem specjalnym wydarzenia był prof. Michał Rusinek. Nagrodzone teksty opublikowano w tomie Zgubiony kapelusz ${ }^{5}$.

Tegoż wieczoru odbył się również w Bibliotece UŁ wernisaż interaktywnej wystawy pt. Umberto Eco \#ksiażka \#literatura \#biblioteka. Pierwsza część ekspozycji, wkomponowana w przestrzeń katalogów kartkowych starego gmachu budynku Biblioteki UŁ, skupiała się na popkulturowym aspekcie myśli Eco, druga miała charakter performatywny. Jak podkreśla jedna z kuratorek wystawy Diana Dąbrowska, celem wystawy była nie tyle ilustracja, co reinterpretacja dzieła Eco.

\section{Eco i czytelnicy}

W trakcie festiwalu czytelnicy mieli możliwość bezpośredniego spotkania z pisarzem w auli Wydziału Filologicznego UŁ. Spotkanie, prowadzone przez prof. Piotra Salwę, dyrektora stacji naukowej PAN w Rzymie, poświęcone było dyskusji nad najnowszą powieścią Eco, satyrą na współczesne dziennikarstwo, zatytułowaną Temat na pierwszą stronę. Autor zaznaczył, że od przeszło trzydziestu lat pisze o wadach współczesnego przekazu medialnego, i podkreślił, że szczególnie interesują go związki współczesności $\mathrm{z}$ wielką historią: tego, co jednostkowe, z tym, co uniwersalne.

$\mathrm{Na}$ pytanie o to, jak pogodzić banalność codzienności z chaotycznością historii, Eco odniósł się do problemu tzw. teorii spiskowych. Nie miał wątpliwości, że spiski istnieją, jednakże - udane czy nie - jego zdaniem zawsze zostaną wykryte i obnażone przed społeczeństwem. Stwierdził, że dla pisarza prawdziwym zagrożeniem jest myśl o spiskach, które nigdy nie zostaną ujawnione, ponieważ nigdy nie istniały. Brak jakichkolwiek dowodów połączony z myśleniem paranoicznym tworzy bowiem niebezpieczną mieszankę. Jej efektem jest lęk przed rzeczywistością i odrzucenie

${ }^{4}$ Potegga intelektu. Umberto Eco: recepcja i reminiscencja w Polsce. Ksiega dedykowana Profesorowi Umbertowi Eco, doktorowi honoris causa Uniwersytetu Łódzkiego (The Power of Intellect. A Book Dedicated to Professor Umberto Eco, Doctor HonorisCausa of the University of Łódź), pod red. Artura Gałkowskiego, Łódź 2015.

${ }^{5}$ Zgubiony kapelusz. Wiersze Wisławy Szymborskiej dla Umberta Eco (Il cappello smarrito. Poesie di Wisława Szymborska per Umberto Eco), red. J. Czerwińska i in., Łódź 2015. 
aktywnego życia w świecie, który wydaje się tylko fasadą, kryjącą globalną i wrogą człowiekowi intrygę.

Eco, zapytany przez wybitnego tłumacza literatury włoskiej Ryszarda Żaboklickiego o to, czy zna polską literaturę, odpowiedział, że wiele jej zawdzięcza. Jako swoich ulubionych autorów wymienił Wisławę Szymborską i Henryka Sienkiewicza. W polszczyźnie najbardziej fascynuje go poziom skomplikowania i wyjątkowości fonetyki. Spytany, czy jako teoretyk wykorzystuje swoją wiedzę w twórczości literackiej, stwierdził, że pisząc, nigdy nie myśli o teorii, ale zawsze pamięta o czytelniku modelowym. Projektuje taką konstrukcję, o której jego czytelnik powie, że chciałby, by ta istniała. Literatura jest więc zdaniem autora nieustanną i ciągłą konstrukcją własnego czytelnika. Autor Szaleństwa katalogowania nie zgadza się z tezą o końcu kultury pisma zastępowanej przez kulturę obrazkową. Istnienie Internetu uznaje za dowód triumfu alfabetu, zaś w globalnej sieci dostrzega możliwości dla rozwoju literatury, opisu i zrozumienia świata.

\section{Dyskusje i konferencje}

Inny z paneli dyskusyjnych (Umberto Eco - eseista, 9 kwietnia 2015 r., prowadzenie prof. Krystyna Pietrych) poświęcony został twórczości eseistycznej autora Imienia róży. Gościem spotkania był Marek Bieńczyk, który mówił o Eco jako obrońcy humanistyki, autorze, który „zawsze pojawia się tam, gdzie ta zaczyna krwawić". Autor Książki twarzy zwracał uwagę na popularyzatorski (a nie: artystyczny) charakter esejów Eco, podkreślając zarazem odmienność własnej koncepcji eseistyki od uprawianej przez Eco. Eseistyka to kaprys, a nie wykład, podkreślał autor niedawno wydanego zbioru Jabłko Olgi, stopy Dawida. To, co najpiękniejsze w życiu, jest dla Bieńczyka intuicyjne i instynktowne. I tego właśnie brakuje mu w twórczości Umberta Eco - artystycznego szaleństwa, które nie musi być podporządkowane dyskursywności i dydaktyczności, a jest wyzwalające w swej nieuchwytności i pasji.

16 kwietnia w Muzeum Kinematografii dyskutowano o związkach semiotyka z kulturą popularną (Rozrywka czy rewolucja? O potencjałach kultury popularnej). W prowadzonej przez Tomasza Załuskiego rozmowie brali udział Tomasz Majewski i Anna Nacher. W toku dyskusji zwrócono uwagę m.in. na dążenie Eco do przełamywania sztucznych podziałów na wysokie i niskie oraz autentyczne i fałszywe, a także na wprowadzoną przezeń kategorię przyjemności, która świadczy o powinowactwach poglądów Eco z Susan Sontag.

Podczas „Labiryntu Znaków” nie mogło zabraknąć spotkania z tłumaczami polskich edycji dzieł Eco(Panel ttumaczy polskich edycji ksiażek Umberta Eco). 21 kwietnia w auli Wydziału Filologicznego spotkali się: Wojciech Soliński (przełożył m.in. W poszukiwaniu języka uniwersalnego), Marta Szymanowska, która reprezentowała zmarłego w roku 2001 męża Adama Szymanowskiego (autora przekładów czterech pierwszych powieści Umberta Ecooraz wielu jego esejów), członkini redakcji „Literatury na Świecie” Anna Wasilewska, nestor italianistyki polskiej, tłumacz trzech ostatnich powieści 
Umberta Eco Krzysztof Żaboklicki, a także Jerzy Jarniewicz, tłumacz tekstów Eco z języka angielskiego.

Dyskutowano na temat fenomenu popularności pisarstwa Umberta Eco w Polsce. Uczestnicy spotkania próbowali odpowiedzieć na pytanie, co sprawia, że lektura tak wymagająca zyskała literacki sukces mający impet kultury masowej. Jak zauważył Soliński, Eco nie marnuje żadnego tematu. Co więcej, rzadko zdarza się, żeby uczony w tak fascynujący sposób mówił o tym, czym się zajmuje. Goście opowiadali o przygotowaniach do tłumaczenia poszczególnych tekstów, o procesie pracy nad przekładem oraz o problemach nieprzekładalności, intertekstualności, nagromadzenia krypto- i autocytatów oraz wielojęzyczności testów Eco.

Punktem wyjścia kolejnej inspirowanej twórczością autora Imienia róży rozmowy ${ }^{6}$, którą poprowadził prof. Tomasz Cieślak, był album $S z a-$ leństwo katalogowania Umberta Eco, nie tylko zbieracza książek, rysunków, obrazów (zgromadził ponad 50 tys. dzieł w swoim mediolańskim mieszkaniu), ale też kolekcjonera idei, faktów historycznych i opowieści. Uczestnicy spotkania zastanawiali się nad sensem katalogowania, zarówno dosłownym, jak metaforycznym. Jacek Dehnel wyróżnił dwa typy zbieraczy: kolekcjonerów typu „francuski encyklopedysta”, szukających wiedzy o świecie poprzez przedmioty, mających potrzebę nazwania i zgromadzenia wszystkiego, oraz poszukiwaczy osobliwości, do których to sam się zaliczył.

Przedmiotem spotkania były również kolekcjonerskie pasje gości: prof. Włodzimierz Nykiel mówił o mapach, a właściwie atlasach, jako rodzajach narracji o świecie m.in. poprzez nazwy geograficzne zależne od dziejów historycznych. Prof. T. Cieślak zauważył natomiast, że kolekcjonerstwo Dehnela wynika z jego melancholijnej dyspozycji. To nie tylko zbieranie faktów, ale też słów, osobliwości języka; czasem zdarzają się zbiory odziedziczone, jak w przypadku opowieści rodzinnych wykorzystanych w Lali, a czasem wokół przedmiotu budowane są ciekawe narracje - jak apokryficzne opisy związane z wystawą XV-wiecznych map w Bibliotece Narodowej.

Ważnymi punktami Festiwalu były konferencje naukowe. W dniach 20-21 IV na Wydziale Filologicznym Uniwersytetu Łódzkiego odbyła się studencko-doktorancka konferencja „ECOMONDO: recepcja twórczości literackiej i myśli naukowej Umberta Eco". Obrady młodych humanistów i semiotyków uświetniła prezentacja specjalnego numeru czasopisma Studenckiego Koła Naukowego Italianistów UŁ: „Ec(c)o ItaliAMO”. W periodyku uczestnicy i słuchacze mogli znaleźć nie tylko program wszystkich wydarzeń związanych z przybyciem Umberta Eco do Łodzi i tejże konferencji, ale także szkice (w wersji polskiej i włoskiej) przybliżające sylwetkę i twórczość profesora Eco.

W dniu uroczystości nadania tytułu doktora honoris causa UŁ prof. Umbertowi Eco rozpoczęła się międzynarodowa konferencja semiotyczna „Znak-myśl-słowo-dzieło” (24-27 V), organizowana przez Zakład

6 Panel dyskusyjny nt. Szaleństwo katalogowania i kolekcjonowania - spotkanie z udziałem JM Rektora UŁ Włodzimierza Nykiela oraz Jacka Dehnela, 5 maja 2015 r. 
Italianistyki KFR UŁ, Zakład Pragmatyki Językowej IA UŁ, Interdyscyplinarne Centrum Badań Humanistycznych UŁ i Istituto Italiano di Cultura di Varsavia. Wykład inauguracyjny wygłosił sam pisarz.

\section{Kryminalna Noc Literatury. Czytanie Umberta Eco}

Interaktywny charakter imprezy zachęcał uczestników do aktywnego udziału w wydarzeniu. Biletem wstępu do Sali Lustrzanej w Muzeum Miasta Łodzi było rozwiązanie zagadki literackiej przygotowanej przez Roztargnionego Bibliotekarza. Wieczór otworzyła dyskusja zatytułowana Syndrom „Millennium", czyli jak szwedzkie kryminaty zmienity postrzeganie gatunku, prowadzona przez dr Natalię Lemann, której gośćmi byli dr Monika Samsel-Chojnacka oraz mgr Rafał Chojnacki.

Potem zaproponowano między innymi „bieg na orientację literacką”, którego celem było rozwiązywanie zagadek ukrytych w pudełkach zapałek rozmieszczonych $\mathrm{w}$ różnych miejscach pałacu. Inną atrakcją była zabawa w pisanie kryminałów pod hasłem „sztylet lub arszenik” rozgrywana $w$ atmosferze przypominającej tę na występach samego Herkulesa Poirota - gracze losowali cytaty z włoskich kryminałów, m.in. Andrei Camilleriego i Donny Leon, opisujące narzędzia i miejsca zbrodni, ofiarę, przestępców oraz poszlaki. I, żeby sprawę dodatkowo utrudnić, „kryminaliści” musieli wpleść w opowiadanie postać Umberta Eco... Efekty były iście demoniczne, takich historii nie powstydziłby się sam Simone Simonini - od opisu mrocznej uczty kanibala z wielkim pisarzem po zwycięską, absurdalnie zabójczą opowieść $\mathrm{z}$ „pantoflem czerwonym jak londyńskie budki telefoniczne” $\mathrm{w}$ tle.

Dla osób preferujących pasywny udział w Nocy Literatury przewidziano gawędy literackie przygotowane przez Joannę Sowę, Krzysztofa Woźniaka, Dariusza Czaję i Jarosława Dylewskiego, czytanie performatywne twórczości Eco, przygotowane przez grupę „ot!czytanie”, oraz bookcrossing.

Spotkania literackie dopełnione były prezentacjami muzycznymi. Ciekawy punkt programu stanowił koncert Duo Milonga (Anety Janiszewskiej i Konrada Salwińskiego), w trakcie którego publiczność usłyszała motywy z filmów i seriali kryminalnych wykonane na akordeonie i harfie, zabrzmiały między innymi melodie z Jamesa Bonda, Ojca chrzestnego, Kryminalnych, Sherlocka, 07 zgłoś się czy Różowej Pantery. Organizatorzy zachęcali do wzięcia udziału w konkursie, którego celem było odgadnięcie jak największej ilości tytułów zaprezentowanych melodii. Ponadto można było usłyszeć koncert piosenki włoskiej w wykonaniu studentów łódzkiej italianistyki oraz improwizację jazzową w wykonaniu uczniów Zespołu Szkół Muzycznych im. S. Moniuszki w Łodzi.

\section{Piękno i brzydota (nie)zdefiniowane}

17 maja w Galerii Akademii Sztuk Pięknych przy ul. Piotrkowskiej 68 odbył się wernisaż realizowanego przez studentów trzech łódzkich uczelni (Pracowni Ubioru ASP, Wydziału Filologicznego UŁ oraz Akademii Muzycznej) słowno-wizualno-muzycznego projektu pt. Piękno i brzydota, którego celem była próba redefinicji tytułowych pojęć. Wykonane przez 
studentów ASP projekty ubiorów dopełnione zostały ich interpretacjami: słowną i muzyczną. Efektem współpracy młodych projektantów, filologów i muzyków były wielowymiarowe opowieści o postrzeganiu i odczuwaniu piękna i brzydoty. Liczne odwołania do popkultury, zagadnień społeczno-historycznych oraz sztuk wizualnych miały stać się dla odbiorców bodźcami do interakcji i prób zbudowania indywidualnych definicji tytułowych pojęć.

Drugą odsłoną projektu, a zarazem uwieńczeniem kilkumiesięcznej pracy ponad siedemdziesięciu studentówbył pokaz mody, który odbył się 26 maja w gmachu Akademii Sztuk Pięknych w Łodzi. Modele ubiorów prezentowane były $\mathrm{w}$ układzie tematycznym i dotyczyły między innymi takich problemów jak: klasyczne i kontrowersyjne definicje piękna, choroby i medyczne ingerencje $\mathrm{w}$ cielesność, śmierć, tandeta. Dopełnienie projektów gestem, ruchem, a także wyświetlanymi w tle grafikami-kolażami utworzonymi ze zdjęć wykorzystanych przez Eco $w$ traktatach zaowocowało wzmocnieniem siły ich wyrazu i nadaniem statycznym dotąd konstrukcjom nowych funkcji, a także zwielokrotnieniem możliwości odczytania.

\section{Koncert kontrastów muzycznych}

Koncert kontrastów muzycznych, odbywający się 5 czerwca w sali koncertowej Akademii Muzycznej w Łodzi, był trzecią i ostatnią częścią projektu pt. Piękno i brzydota, a zarazem wydarzeniem inaugurującym Interdyscyplinarną Konferencję Naukowo-Warsztatową Piękno i brzydota w ujęciu artystycznym i humanistycznym.

Wydarzenie miało charakter synkretycznego $\mathrm{w}$ formie i treści widowiska, którego głównym celem było ukazanie zmienności idei piękna, współistnienia różnych jego modeli oraz procesu redefiniowania piękna na przestrzeni wieków. Całość zbudowana była z dziesięciu sekwencji muzycznych i towarzyszących im komentarzy zaczerpniętych z dzieł Historia piękna i Historia brzydoty Umberta Eco. Każda sekwencja dotyczyła innego zagadnienia, m.in. pochwały Boga, piękna kobiety, piękna w sztuce i filozofii, karykatury, brzydoty cierpienia, matematyki muzyki, fascynacji maszynami czy kontrastu między cywilizacją a naturą. Warstwa muzyczna zachwycała różnorodnością i poziomem wykonania. Zaprezentowano między innymi utwory Bacha, Mozarta, arię operową z Cyrulika sewilskiego, piosenkę Wojciecha Młynarskiego, melorecytację wierszy Rafała Wojaczka, mistrzowskie popisy gry na akordeonie oraz muzykę elektroniczną. Ponadto każdej części słowno-muzycznej towarzyszyła prezentacja zdjęć modeli ubiorów prezentowanych na wernisażu i pokazie mody.

Relację przygotowali doktoranci Instytutu Filologii Polskiej UŁ: Aleksandra Bajerska, Mateusz Grabowski, Alicja Karwowska, Agata Kupracz, Katarzyna Szumska, Anna Zatora. 


\section{STRESZCZENIE}

Sprawozdanie z łódzkiego festiwalu Labirynt Znaków, którego gościem specjalnym był Umberto Eco a wydarzeniem centralnym nadanie włoskiemu pisarzowi tytułu honoris causa Uniwersytetu Łódzkiego.

\section{Słowa kluczowe}

Umberto Eco, festiwal literacki, Labirynt Znaków

\section{S UMM A RY}

Umberto Eco in Łódź, or the Labyrinth of Signs

The report from the Łódź festival Labyrinth of Signs, whose special guest was Umberto Eco, and during which the Italian writer received an honorary doctoratefrom the University of Łódź

\section{Keywords}

Umberto Eco, literary festival, Labyrinth of Signs 